\title{
Induction of IL-8 production in human alveolar macrophages and human bronchial epithelial cells in vitro by swine dust
}

\author{
Lena Palmberg, Britt-Marie Larsson, Per Malmberg, Kjell Larsson
}

\begin{abstract}
Background-Exposure to swine dust causes an intense airway inflammation with increased levels of interleukin 8 (IL-8) and predominantly neutrophils in the nasal and bronchoalveolar lavage fluids of healthy human subjects. It is not clear which components in the swine house environment are responsible for the airway reaction. The aim of the present study was to evaluate and compare the effect in vitro of swine dust components on human alveolar macrophages and bronchial epithelial cells.

Methods-Normal human bronchial epithelial cells (NHBE), human pulmonary epithelial carcinoma cell line (A549), and human alveolar macrophages were stimulated with swine dust, lipopolysaccharides (LPS; present in Gram negative bacteria), grain dust (swine feed components), and glucans (a structural component of fungi) in a dose response manner $(1-100 \mu \mathrm{g} / \mathrm{ml})$. Results-Swine dust at a concentration of $100 \mu \mathrm{g} / \mathrm{ml}$ increased IL-8 production 20 fold in NHBE cells, 28 fold in A549 cells, and 15 fold in macrophages. LPS (100 $\mu \mathrm{g} / \mathrm{ml}$ ) stimulated all three cell types significantly, in macrophages to the same extent as swine dust, but in NHBE and A549 cells swine dust was 5-8 times as potent. Grain dust $(100 \mu \mathrm{g} / \mathrm{ml})$ had no effect in A549 cells but stimulated NHBE cells and macrophages. Glucans $(100 \mu \mathrm{g} /$ ml) stimulated A549 cells and macrophages but not NHBE cells. Both glucans and grain dust were weaker stimuli than swine dust and LPS. The LPS content of swine dust solution was $2.16(0.2) \mathrm{ng} /$ $100 \mu \mathrm{g}$ and of grain dust was $0.53(0.04) \mathrm{ng} /$ $100 \mu \mathrm{g}$.

Conclusions-Swine dust is a strong stimulus for IL-8 production in both bronchial epithelial cells and human alveolar macrophages, whereas LPS has different potency in these cells.

(Thorax 1998;53:260-264)
\end{abstract}

Keywords: airway epithelial cells; alveolar macrophages; swine dust; lipopolysaccharide; IL-8

Interleukin 8 (IL-8) is recognised principally as a chemoattractant and activator of neutrophils and can contribute to inflammatory responses associated with inflammatory lung diseases. This cytokine has been shown to be produced by a number of cell types present in the respi- ratory tract, such as human alveolar macrophages, ${ }^{1}$ bronchial epithelial cells, ${ }^{23}$ fibroblasts, ${ }^{4}$ endothelial cells, ${ }^{5}$ mast cells, ${ }^{6}$ and neutrophils. ${ }^{7}$ The lung epithelial cells constitute an important first line of defence following inhalation of organic dust particles and alveolar macrophages possess a high phagocytic and microbicidal potential. ${ }^{8} \mathrm{~A}$ small number of micro-organisms can be eliminated by alveolar macrophages alone, whereas an inoculum of higher amounts induces influx of neutrophils to the alveoli, attracted by chemotactic substances produced by the macrophages themselves.

Acute exposure of swine dust induces an intense airway inflammation which is characterised by an increased number of inflammatory cells, predominantly neutrophils, and increased levels of cytokines (IL-1, IL-6, TNF- $\alpha$ and IL-8) in bronchoalveolar lavage (BAL) and nasal lavage fluid in previously unexposed healthy human subjects. ${ }^{9-11}$ It is not clear which components in the pig house environment are responsible for the airway reaction. Swine dust consists of many different components including Gram positive and Gram negative bacteria that might contribute to the strong inflammatory reaction in the respiratory tract. ${ }^{12}$ Lipopolysaccharide (LPS) is a component of endotoxin and is present in the walls of Gram negative bacteria. Inhalation of LPS increases the number of neutrophils and lymphocytes in BAL fluid in healthy subjects. ${ }^{13}$ In vitro studies have shown that LPS induces IL-8 secretion in human alveolar macrophages and bronchial epithelial cells. ${ }^{14}{ }^{15}$ Other components of swine dust such as grain dust (swine feed component) and glucans (one of the major structural components of fungi and present in barley) may also be of importance. The aim of the present study was to evaluate and compare the effect of constituents of swine dust on human alveolar macrophages and human bronchial epithelial cells.

\section{Methods}

REAGENTS

Lipopolysaccharide (LPS B E coli 0111:B4, Difco, Detroit, Michigan, USA), glucans ( $\beta$ 1,3-glucan, Wako Pure Chemical Industries, Japan), and grain dust (coarsely milled barley, a swine feed component, collected from the storage container) was diluted in serum-free medium, mixed and put in an ultrasound bath for 10 minutes. Settled (collected approximately $1.20 \mathrm{~m}$ above the floor) swine dust was obtained from a swine confinement building 

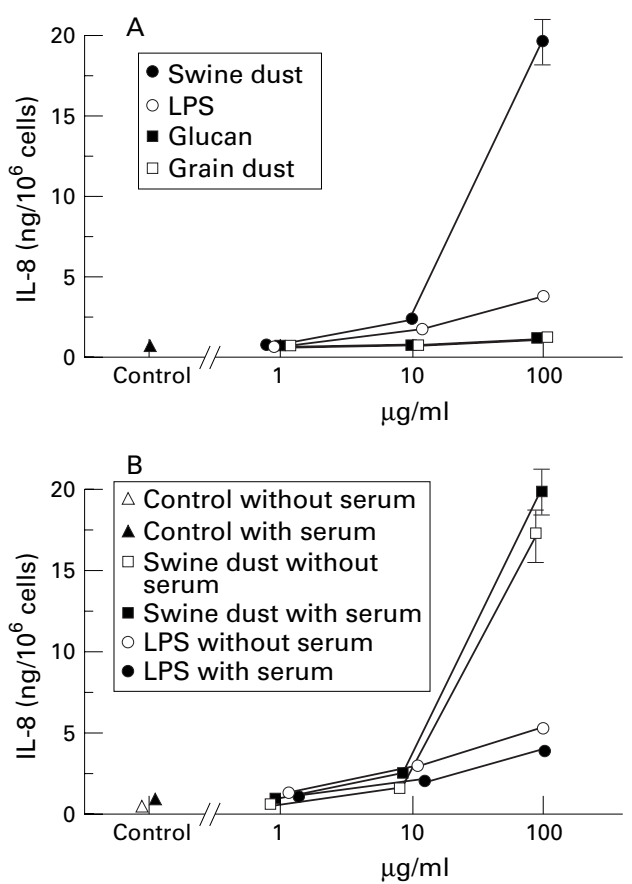

Figure 1 Mean (SE) IL-8 production (ng) per million epithelial cells (A549). Each data point is based on 1-3 experiments performed in triplicate or quadruplicate. (A) Swine dust $(F=83.2 ; p<0.001)$, lipopolysaccharide (LPS) $(F=38.1 ; p<0.001)$, and glucan $(F=4.9$; $p<0.01)$ induced a significant dose-dependent increase in production of IL-8 in A549 epithelial cells. Grain dust did not influence $I L-8$ release $(F=2.3 ; p=0.12)$. LPS stimulated IL-8 production at both $10 \mu \mathrm{g} / \mathrm{ml}(p<0.01)$ and $100 \mu \mathrm{g} / \mathrm{ml}(p<0.001)$ compared with the control. At the highest concentration tested $(100 \mu \mathrm{g} / \mathrm{ml})$ swine dust $(p<0.001)$ and glucan $(p<0.01)$ also stimulated IL-8 production compared with the control. (B) Comparison between incubations of swine dust and LPS with or without serum.

with 700-900 pigs. The dust was dissolved in culture medium to a final concentration of 1 $\mathrm{mg} / \mathrm{ml}$. The dust extract was sonicated for 10 minutes before adding it to the cell cultures. The endotoxin contents of swine dust and grain dust solutions were analysed with the chromogen version of Limulus amebocyte lysate assay (QCL-1000, Endotoxin, BioWhittaker, Walkersville, USA, with $E$ coli 0111:B4 as standard).

PULMONARY EPITHELIAL CELL LINE (A549)

A549 human pulmonary epithelial cells (American Type Culture Collection, Rockville, Maryland, USA), originally derived from a human lung carcinoma, ${ }^{16}$ were cultured. A total of $1-2 \times 10^{6}$ cells were seeded into $80 \mathrm{~cm}^{2}$ plastic flasks (Nunc, Roskilde, Denmark) and grown in medium Ham's F-12 with $10 \%$ fetal calf serum (FCS) and $100 \mu \mathrm{g} / \mathrm{ml}$ penicillin/ streptomycin (Penstrep; Biochrom KG, Seromed, Berlin, Germany). The cultures were kept at $37^{\circ} \mathrm{C}$ in a humidified atmosphere of $5 \%$ $\mathrm{CO}_{2}$ in air and the medium was changed every second day. At confluence the cells were detached by exposure to trypsin/EDTA solution $(0.05 / 0.02 \%$ in calcium- and magnesiumfree phosphate buffered saline; Biochrom KG) and reseeded in 24-well plates at a concentration of $5 \times 10^{4}$ cells/well and grown to subconfluence. Tests for mycoplasma contamination
(SVA, Uppsala, Sweden, performed every third month) were negative.

NORMAL HUMAN BRONCHIAL EPITHELIAL CELLS Normal human bronchial epithelial cells (NHBE) in primary culture (Clonetics Corporation, San Diego, California, USA) were cultured in Bronchial Epithelial Cell Growth Medium (BEGM, Clonetics Corporation). A total of $3.1 \times 10^{5}$ cells were seeded into $80 \mathrm{~cm}^{2}$ plastic flasks and grown in BEGM medium. The cultures were kept at $37^{\circ} \mathrm{C}$ in a humidified atmosphere of $5 \% \mathrm{CO}_{2}$ in air and the medium was changed every second day. At confluence the cells were detached by exposure to trypsin/ EDTA solution $(0.025 / 0.01 \%$ in calcium- and magnesium-free phosphate buffered saline; Clonetics Corporation) and reseeded in 24well plates at a concentration of $4-7 \times 10^{4}$ cells/ well and grown to subconfluence.

PREPARATION OF SUPERNATANTS AND MEASUREMENT OF IL-8 IN EPITHELIAL CELL SUPERNATANTS

At subconfluence $1 \mathrm{ml}$ each of LPS, glucans, grain dust and swine dust at a concentration of 1,10 and $100 \mu \mathrm{g} / \mathrm{ml}$ in Ham's F-12 medium, with or without $10 \%$ FCS, was added to the wells with A549 cells in triplicate or quadruplicate and incubated for 24 hours. At subconfluence $1 \mathrm{ml}$ each of 25,50 and $100 \mu \mathrm{g} / \mathrm{ml}$ swine dust, 50 and $100 \mu \mathrm{g} / \mathrm{ml} \mathrm{LPS}$, and $100 \mu \mathrm{g} / \mathrm{ml}$ grain dust and glucans in BEGM medium was added to the wells with NHBE cells in triplicate and incubated for 24 hours.

All culture supernatant samples were centrifuged at $1000 \mathrm{~g}$ for 10 minutes to remove cell debris and particulate material and stored at $-70^{\circ} \mathrm{C}$ until analysis. Control media were prepared from cell free dishes in the same manner. The cells were detached by trypsinisation and counted in a haemocytometer. Cell viability was determined by the exclusion of trypan blue $(0.4 \%$ in saline; Sera-Lab, Sussex, UK). The IL-8 production per million epithelial cells was analysed in duplicate by enzyme linked immunosorbent assay using a commercial ELISA kit (Quantikine, R\&D Systems, Europe, Abingdon, UK). The lower detection limit of the assay was $31.3 \mathrm{ng} / 1$. For duplicate samples an intra assay coefficient of variation (CV) of $<10 \%$ and an interassay CV of $<20 \%$ was accepted. No significant cross reactivity or interference was observed with 28 tested cytokines and growth factors (information from R\&D Systems)

ALVEOLAR MACROPHAGES

Alveolar macrophages were obtained by bronchoalveolar lavage (BAL) from four healthy non-smoking volunteers. Bronchoscopy was performed through the nose with a flexible fibreoptic bronchoscope (Olympus Type 4B29) under local anaesthesia with lidocaine (Xylocaine; Astra Södertälje, Sweden) after premedication with morphine-scopolamine. The bronchoscope was wedged in a middle lobe bronchus and $250 \mathrm{ml}$ of sterile saline at $37^{\circ} \mathrm{C}$ was instilled in five aliquots of $50 \mathrm{ml}$ each. After each instillation the fluid was gently 


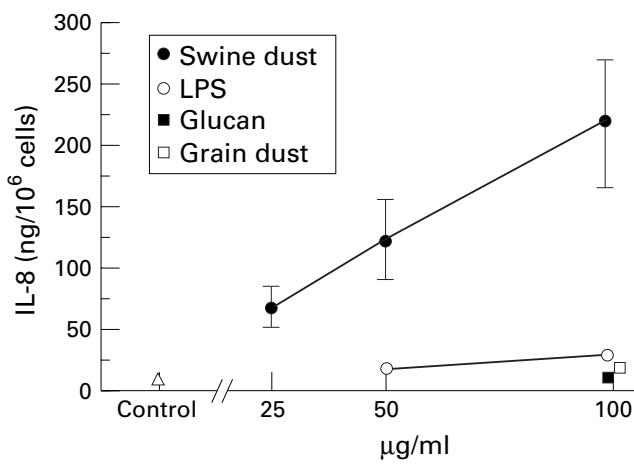

Figure 2 Mean (SE) IL-8 production ( $n g$ ) per million normal human bronchial epithelial cells. Each data point is based on three experiments in triplicate. Swine dust $(F=$ 7.9; $<<0.001)$, lipopolysaccharide (LPS) $(F=7.4$; $p<0.01)$ and grain dust $(F=5.9 ; p<0.05)$ increased $I L-8$ production. Glucan did not influence $I L-8$ release $(F=0.1$; $p=0.82)$. Swine dust stimulated IL-8 production at both $50 \mu \mathrm{g} / \mathrm{ml}(p<0.05)$ and $100 \mu \mathrm{g} / \mathrm{ml}(p<0.001)$ compared with the control. At the highest concentration tested $(100 \mu \mathrm{g} / \mathrm{ml}) \mathrm{LPS}(p<0.001)$ and grain dust $(p<0.05)$ also stimulated IL-8 production compared with the control.

aspirated and collected in a siliconised plastic bottle kept on ice and the recovery was $65 \%$. The cells were pelleted at $200 \mathrm{~g}$ for 10 minutes at $4^{\circ} \mathrm{C}$. The pellet was resuspended in RPMI 1640 medium with $5 \%$ heat inactivated FCS, $50 \mu \mathrm{g} / \mathrm{ml}$ gentamicin, and $100 \mu \mathrm{g} / \mathrm{ml}$ Penstrep (Biochrom KG). The total number of cells was determined by counting in a haemocytometer and cell viability was determined by the exclusion of trypan blue. The total cell count obtained per lavage was $15-25 \times 10^{6}$ and viability was $>85 \%$. Cell differentiation was evaluated using flow cytometry (Epics Profile II, Coulter Electronics Inc, Hialeah, Florida, USA). The samples were prepared in a Coulter Q-prep (Coulter Electronics Inc) and incubated for 10 minutes with CD14-CD45 monoclonal antibodies (Mo2-RD1/Kc56FITC, Cytostat/Coulter Clone, Coulter Corp). A total of $2.5-3 \times 10^{5}$ cells/well was seeded in 24-well plates and incubated for two hours at $37^{\circ} \mathrm{C}, 5 \% \quad \mathrm{CO}_{2}$. Non-adherent cells were removed by gentle washing of the wells with medium and the cells were incubated over night in RPMI 1640 medium with GE and Penstrep. Microscopic examination revealed that the cell population after the adherence step contained $>95 \%$ macrophages.

PREPARATION OF SUPERNATANTS AND

MEASUREMENT OF IL-8 IN CELL SUPERNATANTS FROM MACROPHAGES

After about 18 hours of incubation in serum free medium $1 \mathrm{ml}$ each of LPS, glucans, grain dust and swine dust at a concentration of 1,10 and $100 \mu \mathrm{g} / \mathrm{ml}$ in RPMI 1640 medium with GE and Penstrep were added to the wells in quadruplicate and incubated for eight hours. To study the IL- 8 production over time, swine dust at a concentration of $100 \mu \mathrm{g} / \mathrm{ml}$, or only medium as a control, was added to the wells in quadruplicate for each time point and incubated for $2,4,6,8,10$ and 24 hours, respectively. All culture supernatant samples were collected and centrifuged at $1000 \mathrm{~g}$ for 10 minutes to remove cell debris and stored at $-70^{\circ} \mathrm{C}$ until analysis. IL-8 production was ana- lysed by the ELISA technique using the commercial Quantikine immunoassay and expressed as $\mathrm{ng} / 10^{6}$ macrophages. Cell viability was determined by the exclusion of trypan blue.

STATISTICAL ANALYSIS

Results are presented as mean (SE) values. Statistical comparisons were made by ANOVA with post hoc Fisher's protected least significant difference (PLSD) for each agent separately, and by unpaired $t$ test between substances. A p value of $<0.05$ was considered significant.

\section{Results}

IL-8 PRODUCTION BY A549 EPITHELIAL CELLS

The endotoxin content of the swine dust solutions was $2.16(0.20) \mathrm{ng} / 100 \mu \mathrm{g}$ swine dust and $0.53(0.04) \mathrm{ng} / 100 \mu \mathrm{g}$ grain dust. Baseline IL-8 production in unstimulated A549 cells was $0.71(0.12) \mathrm{ng} / \mathrm{million}$ cells in the presence of serum and $0.26(0.03) \mathrm{ng} /$ million cells under serum-free conditions $(p=0.77)$. Swine dust, LPS and glucans stimulated the pulmonary epithelial cells to produce IL-8 in a dosedependent fashion, swine dust being approximately five times as potent as LPS $(p<0.001)$ and about 15 times as potent as glucans $(\mathrm{p}<0.001)$ at the highest dose $(100 \mu \mathrm{g} / \mathrm{ml}$, fig 1A). However, although glucan was the weakest stimulus, it almost doubled IL-8 production $(90 \%)$ at the highest concentration compared with the control. Grain dust did not alter IL-8 production significantly. Swine dust and LPS stimulated IL-8 production significantly both in the presence and absence of serum (fig 1B). LPS incubation in the presence of serum increased IL-8 production less than under serum-free conditions at the two highest concentrations $(10 \mu \mathrm{g} / \mathrm{ml}, \mathrm{p}<0.05 ; 100 \mu \mathrm{g} / \mathrm{ml}$, $\mathrm{p}<0.001$ ), whereas no significant difference was found when the cells were incubated with swine dust in the absence or presence of serum. There was no IL-8 activity in identically prepared cell-free preparations of swine dust or tested components. LPS incubation with addition of glucan or grain dust $(10 \mu \mathrm{g} / \mathrm{ml})$ did not increase the IL- 8 production compared with incubation with only one component at the same concentration (data not shown). The viability (trypan blue exclusion) remained unchanged $(>90 \%)$ after incubation with all agents at all concentrations.

\section{IL-8 PRODUCTION BY NHBE CELLS}

Baseline IL- 8 production in NHBE cells was 10.8 (1.7) ng/million cells. Swine dust stimulated the NHBE cells to produce IL-8 in a linear dose-dependent manner (fig $2 ; 50 \mu \mathrm{g} / \mathrm{ml}$, $\mathrm{p}<0.05 ; 100 \mu \mathrm{g} / \mathrm{ml}, \mathrm{p}<0.001)$. At the highest concentration swine dust increased IL-8 production 20 fold compared with the control, and significantly more than the other substances tested $(\mathrm{p}<0.01)$. LPS induced a $170 \%$ increase in IL-8 release and grain dust a $70 \%$ increase at $100 \mu \mathrm{g} / \mathrm{ml}$ ( $\mathrm{p}<0.001$ and $<0.05$, respectively). The NHBE cells had a much higher capacity to produce IL-8 per cell (10-15 times) than A549 cells, both under control conditions $(p<0.001)$ 

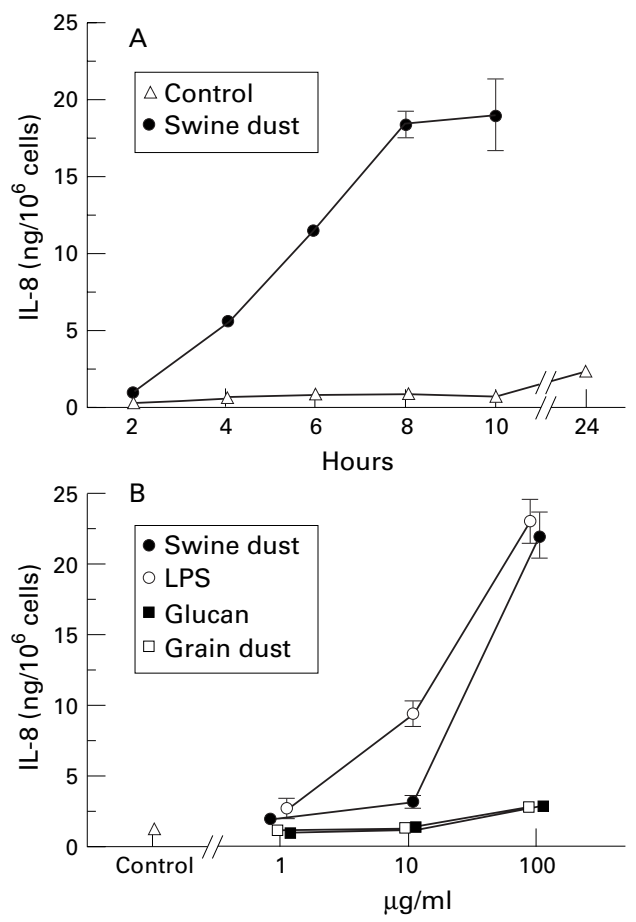

Figure 3 Mean (SE) IL-8 production ( $n g$ ) per million macrophages. (A) IL-8 production over time ( $n=4$ observations). The IL-8 production increased over time, both in the unstimulated control situation $(F=19.4$; $p<0.001)$ and after stimulation with swine dust $(F=97.9$; $p<0.001)$. The IL-8 concentration 24 hours after swine dust stimulation was 113.1 (10.1) ng/million cells which is not shown in the figure. (B) Swine dust $(F=131.3$; $p<0.001)$, lipopolysaccharide (LPS) $(F=105.4$; $p<0.001)$, grain dust $(F=5.5 ; p<0.01)$ and glucans $(F=$ $11.0 ; p<0.001)$ stimulated alveolar macrophages to produce IL-8 in a dose-dependent manner. LPS stimulated $I L-8$ production at both $10 \mu \mathrm{g} / \mathrm{ml}(p<0.001)$ and 100 $\mu \mathrm{g} / \mathrm{ml}(p<0.001)$ compared with the control. At the highest concentration tested $(100 \mu \mathrm{g} / \mathrm{ml})$ swine dust $(p<0.001)$, glucan $(p<0.001)$, and grain dust $(p<0.01)$ also stimulated IL-8 production compared with the control $(n=$ 8 observations with exception of swine dust $1 \mu \mathrm{g} / \mathrm{ml}$ where $n$ $=7$ ).

and after stimulation with swine dust $(100 \mu \mathrm{g} /$ $\mathrm{ml} ; \mathrm{p}<0.001)$. None of the agents tested altered cell viability at any concentration as assessed by trypan blue exclusion (viability $>90 \%$ ).

IL-8 PRODUCTION BY ALVEOLAR MACROPHAGES Baseline IL-8 production in unstimulated macrophages was $1.0(0.09) \mathrm{ng} /$ million macrophages. The IL-8 production increased over time both under control conditions and after incubation with swine dust, but swine dust stimulation resulted in a significantly higher production at all time points tested (fig 3A; $\mathrm{p}<0.001)$. Swine dust, LPS, glucans, and grain dust increased the IL-8 production in alveolar macrophages in a dose-dependent manner (fig 3B). At the highest concentration $(100 \mu \mathrm{g} / \mathrm{ml})$ both swine dust and LPS stimulated the cells to produce more IL- 8 than glucans or grain dust $(\mathrm{p}<0.001)$. However, although glucan and grain dust were much weaker stimuli than swine dust and LPS, they almost doubled IL-8 production $(90 \%)$ at the highest concentration compared with the control. The viability remained unchanged ( $>90 \%$ trypan blue exclusion) after incubation with all agents at all concentrations.

\section{Discussion}

In the present study it has been shown that swine dust is a potent stimulus for IL-8 production in lung epithelial cells (NHBE and A549) and alveolar macrophages, and that the NHBE cells were the most potent IL-8 secretors in this respect. The difference in the capacity of the two epithelial cell types to produce IL- 8 might be explained by the fact that A549 cells constitute a carcinoma cell line while NHBE cells are epithelial cells in primary culture. It is not clear to what extent the functional capacity of the epithelial cells is preserved in a carcinoma cell line and it could be anticipated that the NHBE cells are more similar to normal bronchial epithelial cells in vivo. However, A549 cells still behaved in a similar manner to the NHBE cells, indicating that the cell line cells are quite representative. The difference in incubation time for NHBE cells and macrophages (24 and eight hours, respectively) could in part explain the different capacity of these two cell types. However, stimulation of the macrophages with swine dust for 24 hours increased IL- 8 production more than five times that following eight hours of stimulation, but the macrophages still produced about half the amount produced by the NHBE cells.

Swine dust contains faecal material including micro-organisms, predominantly bacteria of both Gram negative and Gram positive genera. ${ }^{12}{ }^{17}$ LPS is a component of endotoxin present in the walls of Gram negative bacteria. A correlation between symptoms, IL-6 response in BAL fluid and serum, and increased bronchial responsiveness with exposure to contents of endotoxin in swine dust has been shown. ${ }^{10}$ Studies of the capability of LPS to induce IL-8 release in bronchial epithelial cells in vitro have produced contradictory results. ${ }^{15}$ 18-20

LPS was a weaker stimulus than swine dust for IL-8 release in A549 and NHBE cells. The weak effect of LPS on epithelial cells can be explained by the lack of receptors for LPS (scavenger receptor, CD14 and CD18) on these cells. ${ }^{21}$ CD14 recognises complexes of LPS with the serum protein lipopolysaccharide binding protein (LBP) and appears to participate in both ingestion of and synthetic responses to LPS. CD14 is present in two forms, membrane bound (mCD14) or soluble (sCD14). ${ }^{22}$ A549 cells stimulated with LPS were incubated both in the presence of serum, which theoretically could contain both LBP and sCD14, and in the absence of serum, while NHBE cells were incubated under serum-free conditions. However, LPS stimulation of A549 cells under serum-free conditions stimulated IL-8 production to an even higher extent than in the presence of serum, indicating that serum combined with LPS may have an inhibitory rather than a stimulatory effect on IL-8 production .

In alveolar macrophages LPS and swine dust yielded the same response at the highest concentration. Unlike epithelial cells, alveolar macrophages have LPS receptors $(\mathrm{CD} 14)^{21}$ which probably explains the response of macrophages to LPS. However, the endotoxin 
content of swine dust added to the cells was $2.16 \mathrm{ng} / 100 \mu \mathrm{g}$ swine dust. This implies that the LPS content at the highest concentration of swine dust is lower than the lowest LPS concentration used $(1 \mu \mathrm{g} / \mathrm{ml})$ which suggests that components of swine dust other than LPS contribute to the stimulatory effect of swine dust on IL-8 production.

Earlier studies have shown correlation between peptidoglycan (the main constituent of the walls of Gram positive bacteria which is also present in lesser amounts in Gram negative bacteria) and increased numbers of neutrophils in blood and BAL fluid after inhalation of swine dust. ${ }^{11}{ }^{23}$ We have also found that both Gram negative and Gram positive bacteria are potent stimuli for IL- 8 release in A549 cells ${ }^{24}$ and alveolar macrophages. ${ }^{25}$ Gram positive bacterial products have also been shown to stimulate IL-8 production in epithelial cells. ${ }^{24}{ }^{26}$ Gram positive bacteria might also be an important constituent of swine dust, contributing to the inflammatory effect. These experiments strongly support the hypothesis that bacteria-both Gram negative and Gram positive-are involved in the inflammatory airway reaction to inhaled swine dust.

Grain dust may be of importance with regard to the pro-inflammatory activity of swine dust inhalation. Inhalation of an aqueous grain dust extract caused an acute inflammatory response with increased concentration of neutrophils and raised levels of cytokines (IL-6, IL- $1 \beta$, IL-8, and TNF- $\alpha$ ) in BAL fluid. ${ }^{27}$ In the present study grain dust stimulated IL-8 production both in epithelial cells and in alveolar macrophages, but to a much lesser extent than swine dust on a weight basis.

We have previously found that inhalation of swine dust induced increased levels of IL-1 $\beta$ and $\mathrm{TNF}-\alpha$ in lavage fluid from upper and lower airways. ${ }^{10}$ TNF- $\alpha$ appears to initiate cytokine cascades. Human nasal and bronchial epithelial cells both expressed and secreted IL- 8 in primary cultures, and IL- 1 and TNF- $\alpha$ increased mRNA expression and secretion by these cells. ${ }^{328}$ It thus seems probable that the IL-8 response to swine dust is in part mediated by TNF- $\alpha$, although it is unlikely to be the sole mechanism. These findings also indicate that agents in the dust may not only interact directly with the epithelial cells to increase the production of IL-8, but also indirectly through other cytokines.

In conclusion, this study shows that swine dust is a potent stimulus for IL-8 production in lung epithelial cells and alveolar macrophages. LPS had disparate potency in the two cell types tested, indicating that several cell types may contribute to IL- 8 production in the airways by different mechanisms. The low endotoxin content in swine dust and the weak effect of glucans and grain dust to influence IL- 8 release suggest that other components of the swine dust may contribute to the airway inflammatory reaction.

This study was support by grants from the Swedish Council for Work Life Research (94-1383), from The National Work EnviWork Life Research (94-1383), from The National Work Envi-
ronmental Fund (AMFO 90-1680, AMFO 94-0318), The Swedish Farmer Foundation for Agriculture Research, and the
Swedish Heart and Lung Foundation. The authors would like to thank Siw Siljerud for skillful technical assistance.

1 Rankin JA, Sylvester I, Smith S, et al. Macrophages cultured in vitro release leukotriene $B_{4}$ and neutrophil attractant/ activation protein (interleukin 8) sequentially in response to stimulation with lipopolysaccharide and zymosan. 7 Clin Invest 1990;86:1556-64

2 Bédard M, McClure CD, Schiller NL, et al. Release of interleukin-8, interleukin-6, and colony-stimulating factors by upper airway epithelial cells: implications for cystic fibrosis. Am f Respir Cell Mol Biol 1993;9:455-62.

3 Cromwell O, Hamid Q, Corrigan CJ, et al. Expression and Cromwell O, Hamid Q, Corrigan CJ, et al. Expression and
generation of interleukin-8, IL-6 and granulocytegeneration of interleukin-8, $\mathrm{IL}-6$ and granulocytemacrophage colony-stimulating factor by bronchial epithefactor- $\alpha$. Immunology 1992;77:330-7.

4 Rolfe MW, Kunkel SL, Standiford TJ, et al. Pulmonary fibroblast expression of interleukin-8: a model for alveolar macrophage-derived cytokine networking. Am f Respir Cell Mol Biol 1991;5:493-501.

5 Strieter RM, Kunkel SL, Showell HJ, et al. Endothelial cell gene expression of a neutrophil chemotactic factor by TNF- $\alpha$, LPS, and IL-1 $\beta$. Science 1989;243:1467-9.

6 Möller A, Lippert U, Lessman D, et al. Human mast cells produce IL-8. F Immunol 1993;151:3261-6.

7 Strieter RM, Kasahara K, Allen RM, et al. Cytokineinduced neutrophil-derived interleukin-8. Am $\mathcal{f}$ Pathol 1992;141:397-407.

8 Lohmann-Matthes M-L, Steinmüller C, Franke-Ullmann G. Pulmonary macrophages. Eur Respir f 1994; 7:1678-89.

9 Larsson KA, Eklund AG, Hansson L-O, et al. Swine dust causes intense airways inflammation in healthy subjects. Am F Respir Crit Care Med 1994;150:973-7.

10 Wang Z, Larsson K, Palmberg L, et al. Inhalation of swine dust induces cytokine release in the upper and lower airways. Eur Respir f 1997;10:381-7.

11 Larsson B-M, Palmberg L, Malmberg PO, et al. Elevated levels of IL-8 in airway lavage after exposure to swine dust. Thorax 1997;52:638-42.

12 Crook B, Robertson JF, Travers Glass SA, et al. Airborne dust, ammonia, microorganisms, and antigens in pig farm workers. Am Ind Hyg Assoc f 1991;52:271-9.

13 Sandström T, Bjermer L, Rylander R. Lipopolysaccharide (LPS) inhalation in healthy subjects increases neutrophils, lymphocytes and fibronectin levels in bronchoalveolar lavlymphocytes and fibronectin levels in

14 Sylvester I, Rankin JA, Yoshimura T, et al. Secretion of neutrophil attractant/activation protein by lipopolysaccaridestimulated lung macrophages determined by both enzymelinked immunosorbent assay and N-terminal sequence linked immunosorbent assay and N-terminal Am Rev Respir Dis 1990;141:683-8.

15 Khair OA, Devalia JL, Abdelaziz MM, et al. Effect of Haemophilus influenzae endotoxin on the synthesis of IL-6, IL-8, TNF $\alpha$ and expression of ICAM-1 in cultured human bronchial epithelial cells. Eur Respir f 1994;7:2109-16.

16 Leiber M, Smith B, Szakal A, et al. A continuous tumor-cell line from a human lung carcinoma with properties of type II alveolar epithelial cells. Int f Cancer 1976;17:62-70.

17 Attwood P, Brouwer R, Ruigewaard P, et al. A study of the relationship between airborne contaminants and environmental factors in Dutch swine confinement buildings. $\mathrm{Am}$ Ind Hyg Assoc F 1987;48:745-51.

18 Standiford TJ, Kunkel SL, Basha MA, et al. Interleukin-8 gene expression by a pulmonary epithelial cell line. A gene expression by a pulmonary epithelial cell line. A
model for cytokine networks in the lung. 7 Clin Invest 1990; 86:1945-53.

19 Koyama S, Rennard SI, Leikauf GD, et al. Endotoxin stimulates bronchial epithelial cells to release chemotactic factors for neutrophils. A potential mechanism for neutrophil recruitment, cytotoxicity, and inhibition of proliferation in bronchial inflammation. F Immunol 1991;147:4293-301.

20 Ruef C, Jefferson DM, Schlegel-Haueter SE, et al. Regulation of cytokine secretion by cystic fibrosis airway epithelial cells. Eur Respir f 1993;6:1429-36.

21 Wright SD. Multiple receptors for endotoxin. Curr Opin Immunol 1991;3:83-90.

22 Tobias PS, Ulevitch RJ. Lipopolysaccharide-binding protein and CD14 in the lipopolysaccaride-dependent activation of cells. Chest 1994;105(Suppl):49s.

23 Zhiping W, Malmberg P, Larsson B-M, et al. Exposure to bacteria in swine-house dust and acute inflammatory reactions in humans. Am 7 Respir Crit Care Med 1996;154: $1261-6$

24 Larsson B-M, Palmberg L, Larsson K, et al. Gram positive bacteria induce IL-8 production in epithelial cell line A549. Eur Respir f 1995;8:225s

25 Larsson B-M, Palmberg L, Siljerud S, et al. Gram positive bacteria induce IL-8 production in human alveolar macrophages. Eur Respir F 1997;10:43s.

26 Maission PP, Inou H, Richman-Eisenstat J, et al. Novel Pseudomonas product stimulates interleukin-8 production in airway epithelial cells in vitro. $\mathcal{F}$ Clin Invest 1994;93:2632.

27 Clapp WD, Becker S, Quay J, et al. Grain dust-induced airflow obstruction and inflammation of the lower respiratory tract. Am 7 Respir Crit Care Med 1994;150:611-7.

28 Becker S, Koren HS, Henke DC. Interleukin-8 expression in normal nasal epithelium and its modulation by infection with respiratory syncytial virus and cytokines tumor necrosis factor, interleukin-1 and interleukin-6. Am f Respir Cell Mol Biol 1993;8:20-7. 